\title{
Rettskildelære og publikasjonspraksis
}

Av professor dr. juris Svein Eng

Forfatteren tar utgangspunkt i den premiss at rettskildenes publikasjon bør være rettskildemessig nøytral, dvs. at valget av publikasjonsmåte ikke bør påvirke rettskildelærens innhold. Artikkelens hovedkasus til illustrasjon av de prinsipielle spørsmål er prejudikatlæren og betydningen i denne sammenheng av at underrettenes redegjørelse for sakens faktum blir publisert. Forfatteren viser at publikasjonsmåten for dommer i denne relasjon ikke har levet opp til den norm å tjene rettskildelæren. Drøftelsen leder opp til det prinsipielle spørsmål om publiseringen av rettskildene bør organiseres på en annen måte enn i dag, herunder om det overordnede ansvar bør være statlig og lovregulert.

Nøkkelord: ansvaret for rettskildepublisering, grunnlov, offentlig, privat, rettskildelære, rettskildemessig nøytralitet

Svein Eng (f. 1955) er professor i jus og rettsfilosofi ved Det juridiske fakultet, Universitetet i Oslo. Han har publisert arbeider i filosofi, rettsfilosofi, avtalerett, forvaltningsrett og norsk og komparativ rettskildelære.

\section{Innledning}

Drøftelsen i det følgende springer ut av mitt arbeid med dels å klargjøre problemstillingen «rettskildelærens grunnlag», dels å drøfte de substansielle spørsmål som forskjellige tolkinger av problemstillingen reiser. To resultater av dette arbeidet er følgende. For det første, og negativt, argumenterer jeg for at læren om prejudikater ikke får anvendelse på domsargumenter vedrørende rettskildelæren, ${ }^{1}$ og at domstolenes praksis - herunder Høyesteretts praksis - heller ikke på annet grunnlag kan

\footnotetext{
${ }^{1}$ Svein Eng, «Får prejudikatlæren anvendelse på domsargumenter vedrørende rettskildelæren?», Tidsskrift for Rettsvitenskap, 1997 s. 21-44.
} 
tjene som hjemmel og begrunnelse for rettskildelæren. ${ }^{2}$ For det andre, og positivt, argumenterer jeg for at rettskildelærens grunnstruktur settes som en side av, og i dette henseende speiler, grunnlovens normeringer. ${ }^{3}$

Emnet i det følgende - forholdet mellom rettskildelæren og rettskildenes publikasjon - vedrører «rettskildelærens grunnlag» i følgende forstand: Rettskildenes publikasjon er en nødvendig betingelse for en grunnlovsmessig rettskildelære - herunder, og mest fundamentalt, en rettskildelære som lever opp til grunnlovens demokratiprinsipp. ${ }^{4}$ Fra den normative premiss om en grunnlovsmessig rettskildelære følger nærmere bestemt visse normative premisser for rettskildenes publikasjon - bl.a. følgende fire: Rettskildene bør være tilgjengelige, dvs. publiseres; de bør publiseres på en måte som rent faktisk er pålitelig; borgerne bør kunne ha tillit til at publiseringsmåten er pålitelig; og publikasjonsmåten bør være rettskildemessig nøytral, dvs. valget av publikasjonsmåte bør ikke påvirke rettskildelærens innhold.

Idet jeg antar at de tre første premisser er tilstrekkelig selvforklarende i inneværende sammenheng, skal jeg i det følgende fokusere på den fjerde og siste premissen. Denne kan mer litterært angis dit hen at rettskildelærens innhold bør være herren, publikasjonsmåten den lydige tjener. Eller den kan formuleres slik at rettskildelærens innhold bør være det faste punkt, publikasjonsmåten variabelen.

Denne normative premiss er teoretisk og praktisk viktig, men den har ikke fått den oppmerksomhet som dette tilsier. I det følgende skal jeg belegge at og hvorfor premissen slik er viktig, og dertil at den er aktuell uavhengig av publikasjonens ytre form (trykt form, digital form, eller annet). Videre skal jeg som en konsekvens av dette reise spørsmålet om hvem som bør ha ansvaret for publisering av rettskildene.

Mitt hovedkasus vil være prejudikatlæren, og betydningen i denne sammenheng av at underrettenes redegjørelse for sakens faktum blir publisert. Jeg gjør først rede for dette kasus (avsnittene 2-3) og går så på denne bakgrunn over til det prinsipielle (avsnittene 3-4).

\section{Betydningen ifølge prejudikatlæren av at under- rettenes redegjørelse for sakens faktum blir publisert}

\footnotetext{
${ }^{2}$ Svein Eng, ««Rettskildelærens grunnlag»: Problemstillingen og en hovedtese», i Iris Nguyen Duy mfl. (red.), Uten sammenligning. Festskrift til Eivind Smith, Oslo 2020, s. 193-239.

${ }^{3}$ I denne formulering ligger at rettskildelærens grunnstruktur hverken fastsettes uttrykkelig gjennom grunnlovens normeringer eller følger i formelle slutninger fra disse. Det er spørsmål om en viss rettslogisk sammenheng. Se Eng, ««Rettskildelærens grunnlag»: Problemstillingen og en hovedtese», s. 193, 201 jfr. 196-206 og gjennomgående.

${ }^{4}$ Om demokrati som grunnlovens øverste prinsipp, se Eng, ««Rettskildelærens grunnlag»: Problemstillingen og en hovedtese», s. 223-226 og gjennomgående.
} 
Svein Eng, Lov og Rett 59 (2020), ss. 141-48. Før korrektur; ikke for sitering.

Et sentralt spørsmål i læren om prejudikater er hva en dom er prejudikat for. Prejudikatlærens prinsipper om tolking og utfylling av dommer bygger på en forutsetning om dommen som et utslag av en generell norm. Ifølge prejudikatlæren kan den generelle norm ha to grunnlag: Den kan være en del av den begrunnelse som er anført i dommen, isåfall også kalt «den anførte ratio decidendi»; eller den kan representere en begrunnelse som dommen kan og bør ses som utslag av, men som ikke er anført i dommen, isåfall også kalt «en konstruert ratio decidendi». Som et tredje mulig grunnlag for et argument med prejudikatkraft nevnes noen ganger relasjonen mellom det faktum dommen bygger på, og dommens utfall, generalisert til et typetilfelle. En tidligere dom anses da å ha prejudikatkraft hvis den aktuelle sak kan ses som en instansiering av det samme typetilfelle som den tidligere dom. Det er imidlertid vanskelig å trekke noe prinsipielt skille mellom en generell norm som en tidligere dom kan og bør ses som utslag av, og et typetilfelle som dommen instansierer. I begge tilfelle er det tale om generelle kriterier, og i begge tilfelle er spørsmålet hvorvidt kriteriene er anvendelige i både den tidligere og den aktuelle sak. I det følgende bruker jeg derfor termer som «konstruert ratio decidendi» og «konstruert begrunnelse» om begge tilfelle. ${ }^{5}$

Som jurist - det være seg som dommer i en senere sak, som rettsforsker eller som utøver av andre juristroller - står man selvfølgelig ikke fritt til å konstruere en annen begrunnelse.

I bruken av dommer som rettskilde er det to trekk ved de tidligere dommer som vi ikke kan endre, dvs. som vi må behandle som konstanter: Dels må vi ta for gitt de fakta som den tidligere dom bygget på, dvs. de fakta som ble lagt til grunn som bevist i saken. Dels må vi ta for gitt den tidligere dommens konklusjon. Ser vi fakta og konklusjon i sammenheng, kan vi uttrykke denne ramme for bruken av dommer som rettskilde på følgende vis: Vi må ta for gitt settet av de parvise saksfakta og konklusjoner i alle dommer av relevans for det spørsmålet vi søker veiledning i.

Altså, de foreslåtte konstruerte ratio decidendi må i det vesentlige kunne generere de foreliggende dommers parvise fakta og konklusjoner: De forslag til konstruerte ratio decidendi som ikke kan gjøre rede for hvorfor domskonklusjonene ble som de ble, gitt dommenes fakta, anses ifølge prejudikatlæren for i utgangspunktet å ha svakere holdbarhet enn de forslag som kan gjøre rede for domskonklusjonene på bakgrunn av saksfaktaene.

Som et eksempel på den prosess jeg her sikter til, kan vi ta dommene i Rt. 1964 s. 464 og Rt. 1987 s. 199. Umiddelbart synes de uten forbindelse med hverandre. I den første dommen ledet en brann til at en acetylen-beholder eksploderte, med den følge at en tilskuer til brannen omkom. Enken fikk ikke erstatning, heller ikke etter

${ }^{5}$ Om dette punkt, se også Eng, «Får prejudikatlæren anvendelse på domsargumenter vedrørende rettskildelæren?», s. 32-33. Om forskjellige grunnlag for å tildele argumenter prejudikatkraft, se Carl August Fleischer, «Anvendelse og fortolkning av dommer», Jussens Venner, 1965 s. 181-190; Torstein Eckhoff, Rettskildelcre, 1. utgave, Oslo 1971, s. 164-165; 5. utgave ved Jan Helgesen, Oslo 2001, s. 165-166. For en sammenligning mellom norsk og engelsk rett, se Svein Eng, «The Doctrine of Precedent in English and Norwegian Law - Some Common and Specific Features», Scandinavian Studies in Law, Vol. 39, 2000 s. 278-288 (avsnittene 2.32.4). 
ulovfestet objektivt ansvar. I den andre dommen ledet en feilaktig myndighetsutøvelse til at et selskap urettmessig fikk en utpantning mot seg og led tap. Selskapet fikk ikke erstatning, heller ikke etter ulovfestet objektivt ansvar. Den ene dommen behandles i alminnelig erstatningsrett; den andre dommen behandles dels i skatteretten, dels i den alminnelige forvaltningsretten, under drøftelsen av det offentliges erstatningsansvar for urettmessig myndighetsutøvelse.

Men kanskje de to dommene kan og bør ses i sammenheng, nærmere bestemt: Kanskje de to dommenes parvise fakta og konklusjoner kan og bør samles, og begge par ses som et utslag av den samme generelle norm. Ut fra det som ovenfor er sagt om faktum, er det ikke mulig å se hvorfor dette spørsmål skulle reises. La oss da føye til noe mer om faktum i Rt. 1987 s. 199: Saksøker hadde der opprettet intrikate avtale- og selskapsrettslige arrangementer som gjorde det vanskelig for skattemyndighetene å se hvilket rettssubjekt (selskap) som hadde plikten til å trekke skatt og betale arbeidsgiveravgift. Alle disse arrangementer fra saksøkers side var imidlertid fullt ut innenfor handlefrihetens grenser. Ut fra denne opplysning om faktum begynner vi å se muligheten for en felles, generell norm. Den kan forsøksvis formuleres slik: En skadelidt som har benyttet handlefriheten i egen interesse (tilskuer til brann, fastsettelse av kompliserte avtale- og selskapsrettslige arrangementer) på en måte som potensielt vanskeliggjør andre handlinger i fellesskapets interesse (brannslukning, håndhevelse av skattelovgivningen) kan falle utenfor det ulovfestede objektive ansvaret, selv om skadelidtes handlinger isolert sett er fullt ut rettmessige. - Dette vil i tilfelle være en egen og ny kategori på skadelidtes side, i tillegg til begreper som 'skadelidtes medvirkning', 'objektiv yrkesrisiko’ og ‘adekvat årsakssammenheng’.

Det vesentlige i inneværende sammenheng er ikke om man er enig i den nå foreslåtte konstruerte begrunnelse, men at man ser den avgjørende betydning som innsikt i saksfakta har for vår bruk av dommer som rettskilde.

Denne tankestrukturen i bruken av dommer som rettskilde er et rendyrket tilfelle av den analyse- og begrunnelsesmåte jeg betegner «rekonstruksjon og omdefinering»: en særegen analyse- og begrunnelsesmåte, kjennetegnet ved at diskusjonsdeltakerne i det vesentlige er enige om, og behandler som en konstant, et forutsetningsvis avgrenset sett med fenomener (i vårt tilfelle de foreliggende dommers parvise saksfakta og konklusjoner), og hvor uenigheten gjelder hvilke kriterier som er best egnet til å generere det forutsatte settet med fenomener. ${ }^{6}$

I inneværende sammenheng ønsker jeg å framheve følgende to rettskildemessige forhold. For det første: Rekonstruksjons- og omdefineringsstrukturen er utbredt og sentral i vår bruk av dommer som rettskilde. ${ }^{7}$ For det andre: Strukturen forutsetter

\footnotetext{
${ }^{6}$ Svein Eng, U/enighetsanalyse - med scerlig sikte på jus og allmenn rettsteori, Oslo 1998, s. 532-538, 570, jfr. 519-576.

${ }^{7}$ Jeg legger til grunn at den juridiske leser kan se dette ut fra det eksempel jeg har analysert i hovedteksten, et eksempel valgt nettopp fordi det ikke er velkjent og dermed mer egnet til å fokusere på tankestrukturen alene. Det kan være grunn til å nevne at det forutsatte settet med dommer kan bestå i én dom, to dommer, eller et større antall dommer. For tilfelle med to dommer, se eksempelet i hovedteksten, og se forholdet mellom Rt. 1910 s. 231 (kudommen) og Rt. 1912 s. 263 (jernskrapdommen), som blir rekonstruert og omdefinert etter en interessemodell i Sjur Brækhus og Axel Hærem,
} 
Svein Eng, Lov og Rett 59 (2020), ss. 141-48. Før korrektur; ikke for sitering.

at vi har kunnskap om det faktum som hver og en av de tidligere dommer har funnet bevist.

Bare på denne bakgrunn kan man se betydningen av det spørsmål jeg ønsker å reise, nemlig hvorvidt publikasjonspraksis lever opp til den norm å tjene rettskildelæren.

\section{En publikasjonspraksis som ikke lever opp til den norm å tjene rettskildelæren}

Gitt min normative premiss, at publikasjonsmåten for en rettskilde bør være nøytral i forhold til rettskildelæren (avsnitt 1 ovenfor), og gitt den avgjørende betydning ifølge prejudikatlæren av at underrettenes redegjørelse for sakens faktum blir publisert (avsnitt 2 ovenfor), så følger at publikasjonsmåten for dommer bør gjøre det enkelt å finne det saksfaktum som underrettene har funnet bevist, før saken kom til Høyesterett.

Formelt sett var denne fordringen oppfylt fram til 2000, ved at redaktøren av Retstidende i et utvalg av saker trykket de deler av underrettenes dommer som gjaldt bevisbedømmelsen, i tilslutning til Høyesteretts dom.

Reelt sett ble imidlertid fordringen oppfylt i mindre og mindre grad. I forbindelse med et arbeid om prejudikatlæren gjorde jeg for noen år siden en undersøkelse av hvor stor del av sidetallet i Retstidende som ble brukt på utdrag fra byrettens/herredsrettens eller lagmannsrettens beskrivelse av de saksfakta som disse domstolene fant bevist. Resultatet var en jevnt synkende tendens, både i absolutte sidetall og i prosent av sidetallet til vedkommende årgang av Retstidende: 1964, 600 sider (41 \%); 1974, 560 sider (39 \%); 1984, 440 sider (29 \%); 1994, 200 sider (12 \%); 1995, 178 sider (9\%). ${ }^{8}$

Som vi kan forvente, vil vi parallelt med en så markant kvantitativ tendens kunne finne mange tilfelle hvor vi spør etter potensielt relevante saksfakta som

Norsk Tingsrett, Oslo 1964, s. 504-506 jfr. s. 513-514. For tilfelle med mer omfattende domsmateriale, se f.eks. de følgende tre. (i) Rettspraksis om forholdet mellom norsk rett og folkerett blir rekonstruert og omdefinert etter en modell for effektivisering av folkeretten i Carsten Smith, «Den internasjonale rettens innvirkning på den nasjonale retten», Tidsskrift for Rettsvitenskap, 1962 s. 182-204, «Folkerettens stilling ved norske domstoler», Tidsskrift for Rettsvitenskap, 1964 s. 356-374. (ii) Rettspraksis om begrepet 'tilbakevirkende kraft' i grl. § 97 blir i statsrettslig litteratur rekonstruert og omdefinert dels etter en rettighetsmodell, dels etter en kasuistisk rettsregelmodell, dels etter en standardmodell, og dels etter en interesseavveiningsmodell. (iii) Rettspraksis om overgangen fra forberedelse til disposisjon ved avtaler blir rekonstruert og omdefinert etter en avveiningsmodell i kontrast til en rendyrket partsviljemodell i Eng, U/enighetsanalyse, s. 532-536 jfr. 450-454. - For andre illustrasjoner av at rekonstruksjoner og omdefineringer via prejudikatlæren kan være mer eller mindre bredt anlagt, se Eng, U/enighetsanalyse, s. 536-538.

${ }^{8}$ Svein Eng, «Precedent in Norway», i D. Neil MacCormick og Robert S. Summers (red.), Interpreting Precedents, Aldershot 1997, s. 189-217, på s. 195. 
Svein Eng, Lov og Rett 59 (2020), ss. 141-48. Før korrektur; ikke for sitering.

framstår som viktige, men som viser seg å ikke være publisert. Som et i og for seg tilfeldig valgt eksempel kan nevnes Sandsdalen-dommen, Rt. 2000 s. 646. Her gjengir Høyesterett som ledd i sin dom «lagmannsrettens oppsummering av saksforholdet». I denne oppsummering heter det (s. 648): «[Avdøde] underskrev et livstestament 23. mai 1996. Dette er gjengitt i byrettens dom.» Hverken lagmannsrettens eller byrettens redegjørelse for de saksfakta de fant bevist, følger imidlertid Høyesteretts dom i Retstidende. I en prinsipielt viktig sak om rettmessigheten av dødshjelp blir vi altså gjennom en redaksjonell beslutning i publikasjonskanalen avskåret fra kunnskap om et rettslig tilsynelatende tungtveiende moment, nemlig avdødes nøye gjennomtenkte vilje, en vilje som vitterlig foreligger i skriftlig og underskrevet form.

Fra 2001 gikk Retstidende over til kun å publisere Høyesteretts dom.

Mer allment oppstår to problemer ved ikke-publisering av potensielt relevante saksfakta.

For det første fratas vi det nødvendige redskap for å kunne utforske det normative rom som den enkelte sak nettopp ikraft av sine saksfakta er plassert i. Mange forskere i jus har sikkert hatt den opplevelse som består i gjennom lengre tid å ha tenkt over ett eller flere parvise saksfakta og domskonklusjoner, for så plutselig å tenke at disse parvise relasjoner kan ses - kan begrunnes - på en annen måte enn den anførte begrunnelse i den eller de tidligere dommer. Vi står her overfor et av de få rom for oppdagelse og fantasi i rettsdogmatikken. ${ }^{9}$

Det andre problemet som oppstår ved ikke-publisering av potensielt relevante saksfakta, er at vi gjennom publikasjonsmåten tvinges over i en annen bruk av dommer som rettskilde; fokuset i juridisk praksis og forskning forflyttes til de anførte ratio decidendi.

I et maktperspektiv kan vi - alt ellers uforandret - se det slik at den nå utpekte endringen i publikasjonspraksis forskyver makten til å bestemme hva som er rett med utgangspunkt i rettspraksis, fra også å tilkomme juridisk teori til alene å ligge hos Høyesterett. For, juridisk teori konstruerer nye ratio decidendi - alternative kriteriesett til begrunnelse for det foreliggende domsmateriale - og er forsåvidt avhengig av tilgang til en redegjørelse for de saksfakta som i den enkelte dom er funnet bevist. Juridisk teori er nærmere bestemt avhengig av en redegjørelse som ikke er begrenset til de saksfakta som er relevante for den begrunnelse som anføres i dommen; redegjørelsen må ha en viss distanse til den anførte begrunnelse og være åpen for rettslig sett potensielt relevante sider av sakens fakta.

I dag har vi kun Lovdata som publikasjonskanal for dommer. Vi er da avhengig av ett av to. Enten må Høyesterett i sin dom ta inn en like grundig faktumbeskrivelse som vi tradisjonelt kan finne i underrettenes dommer - noe som er lite praktisk gitt prosessrettens regler dels om hvem som har kompetanse til å bedømme de forskjellige bevistemaer og bevismidler, ${ }^{10}$ dels om kravene til domsbegrunnelsen. ${ }^{11}$ Eller så må Lovdata etablere et publikasjonssystem som gjør det

\footnotetext{
${ }^{9}$ Eng, Rettsfilosofi, Oslo 2007, s. 537-540; U/enighetsanalyse, s. 573 jfr. s. 532538.

${ }^{10}$ Se bl.a. tvl. § 21-9 jfr. § 30-11; strpl. §§ 290, 296-300, 327 og 331 jfr. §§ 306 og 340.

${ }^{11}$ Se bl.a. tvl. § 19-6 (5) jfr. (6); strpl. § 40 jfr. § 41.
} 
mulig å finne underrettens saksfakta like enkelt som vi tidligere kunne i Norsk Retstidende.

Man kunne tenke seg å drøfte hva som alt i alt er de mest praktiske måter å ordne dette på, idet man tar dagens organisering av rettskildenes publisering for gitt. De viktige spørsmål kan da imidlertid ikke stilles, for de viktige spørsmål knytter seg nettopp til denne organiseringen.

\section{Bør publisering av rettskildene organiseres på en annen måte enn i dag?}

Det prinsipielt interessante er følgende spørsmål: Gitt den normative premiss om en grunnlovsmessig rettskildelære (avsnitt 1 ovenfor), er det da forsvarlig og alt i alt den beste løsning å overlate til private parter å avgjøre på en formløs måte hvorvidt, og isåfall hvor og hvordan, man skal publisere de rettslig relevante sider av rettskildene - i vårt kasus: hvorvidt, og isåfall hvor og hvordan, man skal publisere underrettens saksfaktum?

Mer spesifikt: Var det forsvarlig og alt i alt den beste løsning at dette tidligere ble avgjort av en redaktør av Norsk Retstidende? Er det forsvarlig og alt i alt den beste løsning at det i dag blir avgjort internt i Lovdata, eller i avtaler mellom f.eks. Lovdata, Høyesterett, og byråkratiet - eller på annen måte som i vår sammenheng framstår som tilfeldig, dvs. uten prinsipiell diskusjon ${ }^{12}$

Dette leder opp til det allmenne og avsluttende spørsmål: Bør publisering av rettskildene organiseres på en annen måte enn i dag - herunder: bør det overordnede ansvar for publisering være statlig og lovregulert?

Bakgrunnen for spørsmålet skulle etter min drøftelse være klar: En publikasjonspraksis med slike trekk jeg har gitt eksempler på, bør unngås. Jeg skal avslutningsvis minne om og framheve særlig følgende trekk: Avgjørelser om publikasjonsmåten som kan tenkes å virke inn på rettskildelæren, blir truffet formløst, av private rettssubjekter, eventuelt etter avtale med offentlige organer uten grunnlag i noen faglig, prinsipiell og offentlig åpen drøftelse av forholdet til rettskildelæren.

For det første blir rettskildene publisert uten noen faglig, prinsipiell og offentlig åpen drøftelse av hvem som bør ha kompetanse til å treffe avgjørelser som kan tenkes å virke inn på rettskildelæren. For det andre blir rettskildene publisert uten noen faglig, prinsipiell og offentlig åpen drøftelse av om avgjørelser som kan tenkes å virke inn på rettskildelæren, er holdbare etter sitt innhold - og da særlig: hvorvidt avgjørelsene om publikasjonsmåten er holdbare ut fra den normative premiss at publikasjonsmåten skal innrette seg etter rettskildelæren, ikke omvendt.

\footnotetext{
${ }^{12}$ For eksempler på avtale og nektelser av avtale, se HR-2019-1725-A, avsnittene 7-8.
} 